\title{
Utilizing Prosodic Information on the Sentence Comprehension in Children with High Functioning Autism
}

\author{
Chan-Hee Chung ${ }^{1}$, Hee-Ran Lee ${ }^{2}$ and Jin-Dong Kim ${ }^{2, \dagger}$ \\ ${ }^{1}$ Hadam Child Development Center, Busan 46252, Korea \\ ${ }^{2}$ Department of Speech and Hearing Therapy, College of Health Science, Catholic University of Pusan, \\ Busan 46252, Korea
}

\begin{abstract}
The purpose of this study is to investigate difficulties in using prosodic information to identify the meaning of ambiguous sentences in children with high functioning autism (HFA). Fifteen high functioning autistic children and fifteen children who matched their chronological age (CA) participated in this study. We compared the performance of the two groups by conducting syntactically and affectively ambiguous sentence comprehension (SASC and AASC) tasks. The results of this study show that in both tasks, the difference between the two groups was statistically significant at each condition and the performance of high functioning autistic children was significantly lower. In a correlation analysis of major variables, children who matched CA showed a correlation between prosody-only (PO) and AASC, while children with HFA showed a correlation between PO and MO (morpheme-only). Children with HFA used grammatical morpheme information to understand general sentences. We found that the ability to use prosodic information in children with HFA is significantly lower than that of normally developed children. Considering the relevance of prosody to linguistic, nonlinguistic and emotional aspects of communication, improving prosodic perception is thought to be a way to mediate deficits in the comprehension of ambiguous sentences in children with HFA.
\end{abstract}

Key Words: High functioning autism, Syntactically ambiguous sentence comprehension, Affectively ambiguous sentence comprehension, Prosodic perception

\begin{abstract}
서 론
인간은 사회 구성원들 간 상호작용을 통해 자신의 생각 을 전달한다. 효과적인 상호작용을 위해서는 정보의 전달 뿐만 아니라 감정을 교류하는 사회적 상호작용이 필요하 다. 언어는 사회적 상호작용의 주요 도구로서 다양한 상 징을 활용하여 내용을 전달한다. 언어의 적절한 사용과 이해를 위해서는 문장 내 포함된 다양한 정보를 활용하여 해당 의미를 결정하는 문장 의미 처리 과정이 필수적이다.
\end{abstract}

이러한 문장 의미 처리 과정은 문장의 분절, 분절된 문장 의 의미 확인 및 연결하는 과정을 포함하고 있으며, 청자 는 이러한 과정을 통해 문장의 구조, 맥락, 화자의 의도 를 파악한다. 운율 정보는 문장 의미 처리 과정의 첫 번 째 과정인 문장 분절 단계에서 매우 중요한 역할을 한다 (Johnson and Jusczyk, 2001)고 알려져 있기 때문에 청자는 복잡한 문장의 통사 구조의 명료화를 위해 이를 활용하는 것이 중요하다.

운율은 화자의 감정, 대화의 초점 등의 맥락상 변인들 의 설정에 따라 그 성격이 결정되며, 이렇게 산출된 문장

*Received: September 17, 2017 / Revised: October 25, 2017 / Accepted: November 2, 2017

${ }^{\dagger}$ Corresponding author: Jin-Dong Kim. Department of Speech and Hearing Therapy, College of Health Science, Catholic University of Pusan, 57 Oryundae-ro, Geumjeong-gu, Busan 46252, Korea.

Tel: +82-51-510-0844, Fax:+82-51-510-0848, e-mail: jdkim@cup.ac.kr

(C) The Korean Society for Biomedical Laboratory Sciences. All rights reserved.

(C) This is an Open Access article distributed under the terms of the Creative Commons Attribution Non-Commercial License (http://creativecommons.org/licenses/by-nc/3.0/) which permits unrestricted non-commercial use, distribution, and reproduction in any medium, provided the original work is properly cited. 
은 운율에도 정보가 내포되어 있기 때문에 문장 이해에 필수적 요소 중 하나가 된다(Chang and Kim, 2005). 또한 운율은 어휘, 구조, 상황적 중의성을 가진 문장 이해에도 도움을 준다. 중의성 문장의 이해(ambiguous sentence comprehension)는 청자가 통사적으로 모호한 문장을 듣고 화 자의 의도를 정확하게 이해하는 것을 의미하는데, 일반적 으로 중의성을 띄는 문장은 화자가 문맥이나 운율 변화를 통해 전달하기 때문에 청자가 이러한 정보를 활용하지 못 할 경우 중의성을 인식하지 못하게 된다. 아동들의 발달 과정에서 운율 처리는 언어의 이해와 표현이라는 관점 에 있어서 언어 습득의 중요한 부분이다. 운율자동처리 (prosodic bootstrapping) 모델과 관련된 연구에 따르면 운율 은 음운, 구문, 의미 발달기 이전부터 습득되는 것으로 보 고 있다(Christophe et al., 2001). 정상 발달 아동의 경우 대 개 3 세 무렵에 운율 수용 능력을 습득하여 긴 문장의 의 미를 파악할 때 강세를 활용하고, 4 5세 정도에는 운율 정보를 성인과 유사한 방법으로 활용하므로 운율 정보의 해석 능력 측면으로만 살펴본 경우 문장을 분별하는 데 어려움이 없다(Beach et al., 1996; Choi and Mazuka, 2003; Kim and Kim, 2004; Choi and Mazuka, 2009). 운율에 따라 다르게 해석할 수 있는 중의성 문장의 경우 3 4세 아동 들도 운율 단독 정보만으로 해당 문장의 의미를 성인과 유사하게 변별 가능하였으며, 운율 정보나 형태소 정보에 따라 다르게 해석 가능한 중의성 문장의 경우 5 6세 아 동도 운율 정보 단독 조건에서는 성인보다 수행력이 유의 하게 낮은 것으로 밝혀졌다(Choi, 2009).

자폐성장애(autism disorders, $\mathrm{AD}$ ) 또는 자폐스펙트럼장애 (autistic spectrum disorders, ASD)는 전체 특수교육 대상 중 세 번째로 높은 비율을 차지하고 있는 장애유형(Special Education Annual Report, 2012)으로 사회관계와 상호작용에 심각하고 지속적인 임상적 결함이 있으며 사회적 상호작 용에 결핍이 있고 이에 사용되는 언어, 비언어적 의사소 통에 두드러진 결함이 존재한다. 자폐성장애 아동의 경우 대개 다른 질환에서 발견되는 것과는 다르게 비전형적인 표현 운율(expressive prosody)을 가지고 있기 때문에 자폐 와 운율 사이의 연관성은 오래 전부터 의심되어 왔다. 자 폐성장애 또는 자폐스펙트럼장애에서 운율과 관련된 16 개 의 연구를 검토한 연구(McCann and Peppé, 2003)에 따르 면, 대부분의 선행 연구는 표현 운율에 중점을 둔 반면 운 율의 수용 기술(receptive skills)에 대한 연구는 거의 없었 다. 대부분의 문헌은 다양한 감정 표현을 이용하여 정서 적 운율의 지각이나 운율에서 정신 상태 또는 정서적 상
태를 이해하는데 주로 중점을 두었다(Kleinman et al., 2001; Rutherford et al., 2002; Golan et al., 2007; Peppé et al., 2007; Järvinen-Pasley et al., 2008). 이들 대부분의 연구는 언어적 단서가 응답에 미치는 영향을 막기 위해 의미적 중립 문 장(semantically neutral sentences)을 사용하여 연구하였는데, 그 결과 자폐성장애를 가지고 있는 아동, 청소년 및 성인 은 연령을 일치시킨 대조집단에 비해 정서 상태를 이해하 는데 필요한 복잡한 음성 표현(예, 당혹감, 자부심)의 처 리에 장애를 보인다고 주장하였다(Kleinman et al., 2001; Rutherford et al., 2002; Golan et al., 2007). 다른 연구에서는 단일 단어 수준에서 음성을 통해 묘사되는 좋아함과 좋 아하지 않음의 확인에서 자폐성장애를 가진 아동의 정 확도 점수가 더 낮은 것으로 나타났다(Peppé et al., 2007; Järvinen-Pasley et al., 2008).

고기능 자폐성장애(high-functioning autism, HFA)는 DeMyer et al. (1981)에 의해 처음 소개되었으며 진단 체계 상 정상 범주에 가까운 자폐성향을 가진 비공식적인 용어 로 수용 및 표현 언어의 수준이 정상 범주이며 상대적으 로 읽기 능력이 우수하지만 화용론과 추론 능력의 어려움 을 가진다. Tsai (1992)는 비언어성 지능이 70 이상이고, 사 회적 상호작용과 의사소통에서 약간의 비정상 또는 발달 의 손상과 제한적이고 반복된 행동을 수반하며 이러한 특 징이 3 세 이전에 출현한다고 하였다. 특히 운율, 강약과 같은 준언어(paralinguistics)와 몸짓, 표정, 목소리의 높낮 이와 같은 비언어적 단서 처리 능력의 결함이 두드러진다 (Paul et al., 2009; Cleland et al., 2010). 특히 고기능 자폐성 집 단은 정상 발달 대조집단과 비교하여 구문적 중의성 문장 에서 구문을 명확하게 하기 위해 운율 정보를 이용할 가 능성이 상당히 낮았으며(Diehl et al., 2008), 운율 단서 및 의 미 단서를 감정과 자연스럽게 통합하는 능력에서 선택적 인 손상을 가지고 있는 것으로 밝혀졌다(Singh and Harrow, 2014).

자폐성장애와 운율 지각 능력 간의 연관성이 존재한다 면 자폐성장애의 일부 측면은 적어도 운율 장애의 측면을 보일 수 있으므로, 이들 간의 상관관계를 확립함으로써 자 폐성장애의 본질에 대한 이해를 높이고 이와 관련된 의사 소통 장애의 일부 측면을 개선할 수도 있을 것이다. 그러 나 자폐성장애에서 운율 장애에 관한 수많은 서술적 설명 에도 불구하고 특히 정상적인 지적 능력을 보유하고 있는 고기능 자폐성장애 집단의 운율 지각 능력에 관한 체계적 인 연구는 제한되어 있다.

따라서 본 연구는 고기능 자폐성장애 아동이 문장의 의 
미 파악을 위해 운율 정보를 처리함에 있어 결함이 있는 지를 조사할 목적으로 고기능 자폐성장애 아동과 생활연 령(chronological age, $\mathrm{CA}$ )을 일치시킨 비장애 아동을 대상 으로 운율 지각 능력을 살펴보았다. 이를 위해 통사적 중 의성 문장 이해(syntactically ambiguous sentence comprehension, $\mathrm{SASC}$ ) 및 정서적 중의성 문장 이해(affectively ambiguous sentence comprehension, $\mathrm{AASC}$ )와 관련된 과제 를 실시하여 상기 두 과제의 수행력을 비교하였다.

\section{재료 및 연구방법}

\section{연구대상자}

본 연구의 진행에 앞서 부산가톨릭대학교 기관생명윤 리위원회(Institute Review Board, CUPIRB)의 승인을 받았다 (승인번호: CUPIRB-2014-043). 또한 실험을 진행하기 전에 연구의 목적, 대상, 진행 절차 및 개인 정보 보안에 대한 안내문을 교사 또는 치료사에게 전달한 후 모든 대상자와 보호자에게 충분한 설명을 제공하였으며 모든 대상자들로 부터 동의서를 받았다. 본 연구의 대상자는 부산 · 경남지 역에 거주하는 초등 저학년(1 3학년)의 고기능 자폐성장 애 아동 15 명, 생활연령을 일치시킨 비장애 아동 15 명으 로, 총 30 명을 대상으로 하였다. 고기능 자폐성장애 아동 은 (1) 소아정신과의사가 실시한 DSM-IV-TR (APA, 2000) 의 진단 기준에 따라 자폐성장애로 진단 받은 아동 또는 상세불명의 전반적발달장애(pervasive developmental disorder not otherwise specified, PDD-NOS)로 진단받거나 의심된다 고 보고된 아동 중 (2) 한국형 아동기 자폐성 평정척도 (CARS, childhood autism rating scale: Kim and Park, 2006)에 서 30점 이상 점수를 획득하고, (3) 한국형 카우프만 아동 용 지능검사도구인 K-ABC (Kaufman Assessment Battery for Korean Children, Moon and Byun, 2009)에서 동작성 지능이 70 이상이며, (4) 표준화된 언어 발달 검사[구문 의미 이해 력 검사(Korea Sentence Comprehension Test, KOSECT) (Pae et al., 2004); 수용·표현어휘력검사(Receptive \& Expressive Vocabulary Test, REVT) (Kim et al., 2009)]에서 정상적인 언 어 발달을 나타내며 시각 및 청각 등의 감각 장애를 동반 하지 않은 아동으로 선정하였다.

생활연령일치 아동은 부모 및 교사에 의해 언어 능력 및 지적 능력이 정상이라고 보고된 아동 중에 (1) 수용·표현 어휘력검사 결과 해당 연령의 -1 SD (Standard Deviation) 이상인 아동 중 (2) K-ABC (Moon and Byun, 2009)의 동작 성 지능이 85 이상이고, (3) 고기능 자폐성장애 아동과 생
활연령을 \pm 3 개월 이내로 일대일 대응시킨 아동들로 선 정하였다.

\section{연구 도구}

통사적 중의성 문장 이해 과제는 Choi and Mazuka (2003) 및 Choi (2009)의 실험을 수정, 보완해서 제작하였다. 문장 이해에 운율 정보가 독자적으로 기여하는 정도를 검토하 기 위해 각 문장의 단서를 운율 단독(prosody-only, PO), 형 태소 단독(morpheme-only, MO), 운율+형태소 복합(prosody +morpheme, PM) 조건으로 분류하여 두 가지 의미로 해석 될 수 있는 문장을 사전에 녹음한 후 대상자에게 들려주 고, 각 단서에 따른 두 집단(아동 고기능 자폐성장애 아동, 생활연령을 일치시킨 비장애 아동)의 수행력 차이를 확인 하였다.

운율 단독 조건은 "무엇 먹어?"와 같은 문장을 형태소 를 비롯한 문법적인 정보를 생략하고 제시했을 때 대상자 가 운율 정보만으로 의미를 파악하고 의미에 맞게 답을 하는지를 살펴보았다. 첫 번째로 제시되는 문장의 예로 "무엇을 먹니?"는 어떤 음식을 먹고 있느냐를 묻는 경우 로, 무엇과 먹어 사이에 쉼이 없거나 짧다(구체적 답변 조 건). 둘째 역시 "무엇 먹어?" 라는 문장이지만 무언가를 먹고 싶니/있니? 라는 의미로 '무엇'과 '먹니' 사이에 쉼이 상대적으로 길고, 첫 단어인 '무엇' 끝을 살짝 올려서 읽는 경우(네/아니요 답변 조건)를 말한다. 형태소 단독 조건은 운율 단서 대신 형태소 단서만으로 문장을 파악할 수 있 는가를 평가한다. 운율 정보를 없애기 위해 addcast MEDIA TECHNOLOGY 사의 문자음성(text-to-speech)변환 프로그 램인 Vocalware (New York, NY. USA)를 이용하여 각 음절 의 고저 없이 동일한 톤과 진폭을 유지하도록 하였다. 형 태소+운율 복합 조건은 운율과 형태소 단서를 모두 제시 하는 문장으로, 일반적인 의사소통 상황에서 문장을 말할 때와 동일한 경우이다. 검사 문항은 "붕어빵먹어요"와 같 은 통사적 중의성 문장으로 '붕어가 빵을 먹는다'처럼 <주 어+목적어+서술어>로 해석되는 문장과 '누군가 붕어빵을 먹는다'와 같이 <목적어+서술어>로 해석될 수 있는 문장 으로 문항 구성을 하였다. 측정 조건별 검사 문항은 총 14 문항으로 <주어+목적어+서술어>로 해석되는 문장 7 문항 과 <목적어+서술어>로 해석되는 문장 7 문항으로 구성하 였다. 각 조건별 문항은 Syntrillium Software Corporation 사의 무료 음원편집 프로그램인 Cool Edit v2.1 (Phoenix, $\mathrm{AZ}, \mathrm{USA}$ )로 녹음 후 무료 음성 분석 프로그램인 Praat (Spuistraat, Amsterdam, Netherlands)을 통해 분석하였다. 최 
종 선정 문항은 Adobe Systems의 Adobe Flash (San Jose, CA, $\mathrm{USA}$ )로 제작하여 아동에게 검사를 진행하였다.

정서적 중의성 문장 이해 과제는 Park (2010)과 Kleinman et al. (2001)의 운율에 따른 정서 구분 과제를 참고하여 제 작하였다. 문장은 <주어+목적어+서술어>로 구성되며 6 9음절로 통제하였다. 해당 과제는 운율을 이용하여 문장 의 정서 구분할 수 있도록 의미적으로 중의적 정서를 가 진 8 문장에 3 가지 일차적인 감정(기쁨, 슬픔, 화)의 운율을 각각 실어서 총 24 문항을 만든 후, 감정을 대표할 수 있는 그림(웃는 표정, 우는 표정, 화난 표정)을 Adobe Flash (San Jose, $\mathrm{CA}, \mathrm{USA}$ )로 제작하여 아동에게 적절한 그림을 선택 하도록 요구하였다. 정서적 중의성 문장 이해 과제의 모든 문장들은 Cool Edit v2.1 (Phoenix, AZ, USA)로 녹음하였다.

\section{연구 과제 제작 과정 및 타당도 검증}

본 연구를 진행하기에 앞서 적절한 검사 문항을 개발 하기 위해 통사적 중의성 문장 이해 과제에 사용할 문장 10 개와 정서적 중의성 문장 이해 과제에 사용할 문장 8 개 를 각각 선정하였다. 통사적 중의성 문장 이해 과제의 음 성은 전직 기상 캐스터에게 의뢰하여 제작하였고, 정서적 중의성 문장 이해 과제의 음성은 경력 10 년의 구연동화 강사에게 의뢰하여 제작하였다.

제작된 그림과 음성의 내적 타당도를 알아보기 위해 경 력 3 년 이상의 고기능 자폐성장애 아동을 중재 중인 언어 치료사 3 명이 검토 후 검사 문항과 그림에 대한 정반응이 낮은 문장과 그림에 대한 정반응이 낮은 통사적 중의성 문장 이해 과제 문항 3 개를 제외하였다. 본 연구를 위해 선정된 통사적 중의성 문장 이해 과제 문항은 총 21 개, 정 서적 중의성 문장 이해 과제 문항은 총 24 개였다.

\section{연구 절차}

조용한 방에서 대상자가 과제에 집중할 수 있도록 검 사 장소를 최대한 통제하였다. 모든 실험 과제는 개별적 으로 실시하였으며, 연구자와 마주보고 앉은 상황에서 실 험을 진행하였다. 본 연구에서 제작된 Flash 파일을 태블 릿(tablet)에 저장한 후 대상자에게 과제를 제시하였으며, 대상자는 제시되는 문장을 들은 후 터치스크린을 이용하 여 응답하도록 요청하였다. 본 연구자는 대상자들의 통사 적 중의성 문장 이해 과제와 정서적 중의성 문장 이해 과 제의 검사 결과 확인에 사용하기 위해 연습 과제가 실시 되기 이전부터 대상자 별 과제 풀이 진행 동안 지속적으 로 영상을 녹화를 하였다.
본 연구는 연구 대상자들에게 충분한 휴식 시간을 제공 하기 위해 통사적 중의성 문장 이해 과제를 먼저 실시한 후 충분한 간격을 두고 정서적 중의성 문장 이해 과제를 실시하였다. 각 과제의 문항 간 간격은 대상자가 문항에 대한 응답을 한 후, 2초 후 다음 문항이 제시되도록 설정 하였다. 각 과제는 본 과제 전 세 개의 연습 과제를 두어 대상자의 이해를 돕고, 만약 대상자가 문항을 이해하지 못 할 경우 검사를 중지하였다. 또한 대상자의 요구가 있을 시 한 번 더 들려주고 이후 선택하지 못할 시 오답으로 처리하였다.

통사적 중의성 문장 이해 과제는 중의성을 띈 문장을 각 단서별로 나누어 운율+형태소 복합, 형태소 단독, 운율 단독 순서로 실시하였으며, 각 문장은 운율 및 형태소 단 서의 배치에 따라 의미가 달라질 수 있는 문장으로 구성 되었다. 정서적 중의성 문장 이해 과제는 의미적 중립 문 장에 세 가지 감정(기쁨, 슬픔, 화)을 실어 총 24문항으로 구성되었으며, 동일한 문장 또는 정서가 중복되지 않게 배 치하였다.

\section{자료 분석 및 통계 처리}

각 과제는 아동이 선택한 그림이 제시된 문장과 일치하 면 1점, 그렇지 않으면 0점을 부여하였다. 고기능 자폐성 장애 아동과 생활연령이 일치하는 비장애 아동의 운율 정 보 활용이 중의성 문장 이해력에 미치는 영향과 집단 간 차이를 비교하기 위해 다음과 같이 분석하였다.

첫째, 통사적 중의성 문장 이해 과제에서 단서에 따라 문장 이해의 차이를 알기 위해 이요인 반복측정 분산분석 (Two way repeated measures ANOVA)을 실시하였다. 집단 내 요인은 운율 단독 조건, 형태소 단독 조건, 운율+형태 소 복합 조건으로 설정하였으며, 집단 간 차이는 고기능 자폐 아동, 생활연령일치 아동으로 구분하여 수행력을 살 펴보았다. 각 집단 내에서 조건에 따른 수행력을 반복 측 정하여 단서의 주 효과 및 집단과 단서 간의 상호작용 효 과를 살펴보았다. 또한 고기능 자폐성장애 아동과 생활연 령일치 아동 집단 간 통사적 중의성 문장 이해 과제에서 유의미한 차이가 있는지를 알기 위해 $t$-검정을 실시하였다. 둘째, 정서적 중의성 문장 이해 과제에서 집단 간 운율 지 각에 따른 정서 이해의 차이를 알기 위해 일원분산분석 (one-way ANOVA)을 실시하였다. 셋째, 통사적 중의성 문 장 이해 과제의 단서(운율 단독, 형태소 단독, 운율+형태 소 복합)와 정서적 문장 이해 과제 간 상관관계를 알기 위 해 Pearson 상관분석(correlation analysis)을 실시하였다. 본 
연구에서는 SPSS for Window 21을 사용하여 자료 분석을 실시하였다.

\section{결 과}

\section{통사적 중의성 문장 이해}

고기능 자폐성장애 아동과 생활연령일치 아동 두 집단 의 통사적 중의성 문장 이해 점수에 집단 간 차이가 있는 지 알아보기 위하여 조건에 따른 집단 간 문장 이해 능력 을 살펴보았다. 집단 간 기술통계 결과는 Table 1 과 같다 (Fig. 1. 참조). 고기능 자폐성장애 아동의 전체 평균 점수 는 $10.1(\mathrm{SD}=2.57)$, 생활연령일치 아동의 전체 평균 점수 는 $12.8(\mathrm{SD}=1.23)$ 로 생활연령일치 아동이 고기능 자폐성 장애 아동보다 높게 나타났다. 이를 조건 별로 살펴보면 세 단서 조건(운율 단독 단서, 형태소 단독 단서, 운율+형 태소 복합 단서)에서 고기능 자폐성장애 아동보다 생활연 령일치 아동에서 통사적 중의성 문장의 이해력이 높게 나

Table 1. Descriptive statistics of syntactically ambiguous sentence comprehension performance by HFA and CA groups

\begin{tabular}{lcccc}
\hline \multicolumn{1}{c}{ Conditions } & PO & MO & PM & $\begin{array}{c}\text { Total } \\
\text { scores }\end{array}$ \\
\hline HFA $(\mathrm{n}=15)$ & 8.8 & 11.5 & 10.1 & 10.1 \\
& $(2.34)$ & $(2.67)$ & $(2.71)$ & $(2.57)$ \\
$\mathrm{CA}(\mathrm{n}=15)$ & 11.5 & 13.5 & 13.4 & 12.8 \\
& $(2.26)$ & $(0.52)$ & $(0.91)$ & $(1.23)$ \\
Total $(\mathrm{n}=30)$ & 10.2 & 12.5 & 11.8 & 11.5 \\
& $(2.3)$ & $(1.60)$ & $(1.81)$ & $(1.9)$ \\
\hline
\end{tabular}

Values are presented as mean (SD).

Abbreviations: HFA, high-functioning autism; CA, chronological age; PO, Prosody-only condition; MO, Morpheme-only condition; PM, Prosody+Morpheme complex condition.
타났다. 이러한 결과가 통계적으로 유의 한지 알아보기 위 해 이요인 반복측정분석을 실시하였는데, 이 결과에 따르 면 집단 $\left(F_{(1,28)}=25.06, P<0.001\right)$ 및 단서의 주 효과 $\left(F_{(2,56)}=\right.$ $13.21, P<0.001)$ 가 발견되어 통계적으로 유의한 것으로 밝 혀졌으나, 단서와 집단의 상호작용효과는 통계적으로 유 의하지 않은 것으로 나타났다(Table 2). 단서에 따른 주 효 과가 나타났기 때문에 어떤 단서 간에 통계적으로 유의한 차이가 있는지를 확인하기 위해 대응표본 검정을 실시하 였다(Table 3). 이 검정 결과에 따르면 고기능 자폐성장애 아동 집단은 통사적 중의성 문장을 이해하는데, 형태소 단 독 단서, 운율+형태소 복합 단서, 운율 단독 단서 순으로 수행력이 높은 것을 알 수 있었다. 또한 형태소 단독 조건 과 운율+형태소 복합 조건, 운율+형태소 복합 조건과 운 율 단독 조건, 운율 단독 조건과 형태소 단독 조건 간에 유의한 수행력의 차이점이 발견되었다.

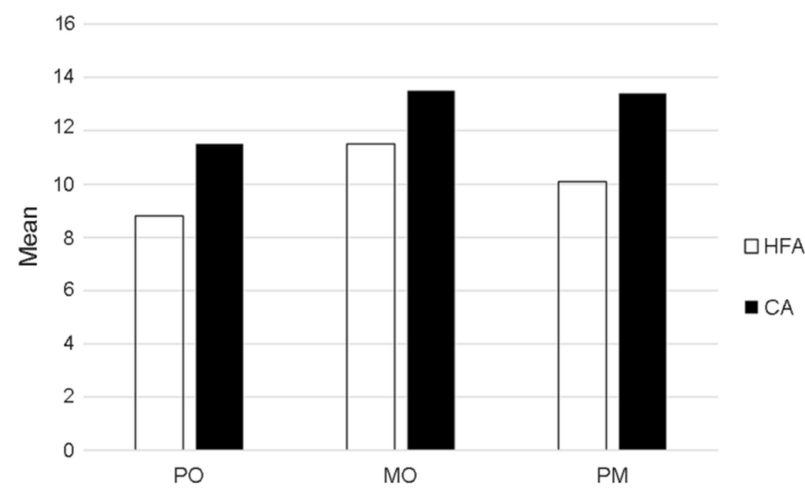

Fig. 1. Mean scores of syntactically ambiguous sentence comprehension performance by HFA and CA groups. Abbreviations: HFA high-functioning autism; CA, chronological age; PO, Prosody-only condition; MO, Morpheme-only condition; PM, Prosody+Morpheme complex condition.

Table 2. Two way repeated measures ANOVA for syntactically ambiguous sentence comprehension performance

\begin{tabular}{llrrrr}
\hline \hline \multirow{2}{*}{ Between groups } & \multicolumn{1}{c}{ Source } & \multicolumn{1}{c}{ SS } & df & Mean square & $F$ \\
& Groups & 162.00 & 1 & 162.68 & $25.06^{* * *}$ \\
\multirow{3}{*}{ Within } & Errors & 181.78 & 28 & 6.50 & $13.21^{* * *}$ \\
& Conditions & 86.96 & 2 & 43.48 & .37 \\
& Conditions ${ }^{*}$ groups & 6.69 & 2 & 3.35 & 3.30 \\
\hline
\end{tabular}

$P$-values $<0.05,0.01$ and 0.001 are indicated by ${ }^{*},{ }^{* *}$ and ${ }^{* * *}$, respectively. 
Table 3. Paired sample T-test for syntactically ambiguous sentence comprehension performance in HFA group

\begin{tabular}{lcccc}
\hline \hline Conditions & $\begin{array}{c}\text { Mean } \\
\text { difference }\end{array}$ & $\begin{array}{c}\text { Standard } \\
\text { error }\end{array}$ & $t$ & Conditions \\
\hline PO-MO & 2.36 & .55 & $-4.30^{* * *}$ & $10.1(2.57)$ \\
MO-PM & .80 & .30 & $2.62^{*}$ & $12.8(1.23)$ \\
PM-PO & 1.56 & .52 & $3.03^{* *}$ & $11.5(1.9)$ \\
\hline
\end{tabular}

$P$-values $<0.05,0.01$ and 0.001 are indicated by ${ }^{*},{ }^{* *}$ and ${ }^{* * *}$, respectively.

Abbreviations: PO, Prosody-only condition; MO, Morpheme-only condition; PM, Prosody+Morpheme complex condition

Table 4. T-test of affectively ambiguous sentence comprehension performance by HFA and CA groups

\begin{tabular}{lccc}
\hline \hline & $\mathrm{M}(\mathrm{SD})$ & Standard Error & $t$ \\
\hline HFA & $15.13(4.15)$ & 1.07 & $2.49^{*}$ \\
CA & $19.13(4.64)$ & 1.20 & \\
\hline$P-V$ &
\end{tabular}

$P$-values $<0.05$ are indicated by ${ }^{*}$.

Abbreviations: HFA, high-functioning autism; CA, chronological age.

\section{정서적 중의성 문장 이해}

고기능 자폐성장애 아동과 생활연령일치 아동의 운율 지각에 따른 정서적 중의성 문장 이해 능력에 차이가 있 는지 알아보기 위하여 $t$-검정을 실시하였다(Table 4). 두 집단의 정서적 중의성 문장 이해 과제의 수행력을 비교 해 본 결과 고기능 자폐성장애 아동의 전체 평균 점수는 $15.13(\mathrm{SD}=4.15)$ 이고, 생활연령일치 아동의 전체 평균 점 수는 $19.13(\mathrm{SD}=4.64)$ 으로 나타났다. 고기능 자폐성장애 아동은 생활연령일치 아동보다 정서적 중의성 문장을 이 해하는데 어려움을 보였으며, 두 집단의 수행력은 통계적 유의한 차이 $(t=0.019, P<0.01)$ 를 나타내었다.

\section{통사적 중의성 문장과 정서적 중의성 문장 이해력의 상 관관계}

고기능 자폐성장애 아동의 통사적 중의성 문장 이해력 과 정서적 중의성 문장 이해력 간의 상관관계를 확인하기 위해 Pearson 상관계수를 구하였다(Table 5). 상관분석 결과, 고기능 자폐성장애 아동 집단은 운율+형태소 복합 단서와 형태소 단독 단서는 유의한 상관 $(r=0.73)$ 을 보여주었으나 그 외, 다른 변인 간에는 상관관계를 보이지 않았다.

생활연령일치 아동의 통사적 중의성 문장 이해력과 정 서적 중의성 문장 이해력 간의 상관관계를 확인하기 위해
Table 5. Pearson correlation coefficients between variables of syntactically and affectively ambiguous sentence comprehension performance in HFA group

\begin{tabular}{lcccc}
\hline \hline & PM & PO & MO & AASC \\
\hline PM & & .059 & $.735^{* *}$ & .341 \\
PO & & .041 & .334 \\
MO & & & & .077
\end{tabular}

AASC

$P$-values $<0.05,0.01$ are indicated by ${ }^{*},{ }^{* *}$, respectively. Abbreviations: HFA, high-functioning autism; PO, Prosody-only condition; MO, morpheme-only condition; PM, Prosody+Morpheme complex condition; AASC, affectively ambiguous sentence comprehension.

Table 6. Pearson correlation coefficients between variables of syntactically and affectively ambiguous sentence comprehension performance in CA group

\begin{tabular}{lcccc}
\hline \hline & PM & PO & MO & AASC \\
\hline PM & & .409 & .122 & .172 \\
PO & & .383 & $.530^{*}$ \\
MO & & & .058 \\
AASC & & & & \\
\hline
\end{tabular}

$P$-values $<0.05$ are indicated by ${ }^{*}$.

Abbreviations: HFA, high-functioning autism; CA, chronological age; PO, Prosody-only condition; MO, morpheme-only condition; PM, Prosody+Morpheme complex condition; AASC, affectively ambiguous sentence comprehension.

Pearson 상관계수를 구하였다(Table 6). 상관분석 결과, 운 율+형태소 복합 단서는 다른 변인 간 상관관계를 보이지 않았으나, 운율 단독 단서는 정서적 운율 이해 과제와 유 의한 상관 $(r=0.530)$ 을 보여주었다. 형태소 단독 단서와 정 서적 중의성 문장 이해 과제와는 유의한 상관관계를 보이 지 않았다.

\section{고 찰}

자폐성장애 환자의 운율 지각 양상은 유아기에 손상될 수도 있으며(Kuhl et al., 2005), 이들의 운율적 결함은 자폐 성장애 아동의 초기 발달 과정에 있어서 가장 먼저 드러 나는 문제로 의사소통에 크게 영향을 미치지 않는 아동부 터 심각한 결함으로 이어지는 아동까지 편차가 매우 크게 나타난 것으로 보고되고 있다(Bonneh et al., 2011; DePape et al., 2012). 이러한 운율적 결함의 차이는 사회성 및 의사 
소통 기능의 등급과 유의하게 관련이 있는 것으로 밝혀졌 으며(Paul et al., 2005), 자폐성장애 아동의 가장 큰 문제는 운율적 이상이 다른 언어 영역의 발달에 관여할 뿐만 아 니라 인생 전반에 걸쳐 계속 영향을 미친다는 점에 있다

(Schoen et al., 2010).

본 연구는 고기능 자폐성장애 아동과 생활연령일치 아 동을 대상으로 문장 의미 처리 과정에서 운율 정보를 활 용하여 문장의 의미를 이해하고 정서를 파악하는 능력에 차이가 있는지 확인하기 위해 통사적 중의성 문장 이해 과제와 정서적 중의성 문장 이해 과제를 실시하였다. 먼 저, 통사적 중의성 문장 이해 과제의 총 점수를 비교한 결 과, 3 가지 세부 과제인 운율 단독 조건, 형태소 단독 조건, 운율+형태소 복합 조건 모두 고기능 자폐성장애 아동은 생활연령일치 아동에 비해 수행력이 저하되어 있어 언어 적 능력에 차이가 있는 것으로 나타났다. 그러나 두 집단 의 아동들은 모두 형태소 단독 조건, 운율+형태소 복합 조건, 운율 단독 조건의 과제 순으로 수행력이 높게 나타 났으며, 특히 고기능 자폐성장애 아동과 생활연령일치 아 동 두 집단 모두 운율+형태소 복합 단서와 형태소 단독 단서가 제시되었을 때보다 운율 단독 단서가 제시되었을 때 수행력이 더 낮았다. 또한 고기능 자폐성장애 아동은 세 단서(운율 단독, 형태소 단독, 운율+형태소 복합) 모두 에서 문장 이해 능력이 생활연령일치 아동 집단보다 유의 미하게 낮은 것으로 나타났다. 이는 고기능 자폐성장애 아동과 생활연령일치 아동 집단 간 통사적 중의성 문장 이해에 차이를 보이며, 고기능 자폐성장애 아동 집단 내 에서 각 단서에 따라 이해 능력의 차이를 보이는 것으로 비록 고기능 자폐성장애 아동이 생활연령일치 아동에 비 해 언어적 발달은 늦지만, 발달 과정은 비슷한 것으로 유 추할 수 있다. 본 연구에서 확인한 일반 아동들의 결과는 학령전기 아동(3 6세)을 대상으로 운율 정보 탐지와 더불 어 이를 문장 해석에 적절히 적용할 수 있는 조건에 대해 살펴본 Choi (2009)의 연구 결과와 일치한다. 운율 정보나 형태소 정보에 따라 다르게 해석이 가능한 중의성 문장에 대한 이해를 운율, 형태소, 그리고 운율과 형태소 복합 정 보 조건에서 실시한 결과 운율과 형태소 복합 조건, 형태 소 조건에서 5 6세 아동의 수행력은 성인의 수준과 거의 유사한 반면 운율 조건에서는 성인보다 유의하게 낮은 것 으로 밝혀졌다. 즉, 형태소 정보는 아동의 문장 이해에 기 여하는 바가 크다는 것을 확인할 수 있으며, 운율 정보만 을 단독으로 활용하는 능력은 학령 전 시기 아동에게는 아직 어렵다고 보여진다. 그러나 이러한 운율 정보를 형
태소 정보와 통합하여 문장 의미 이해에 활용할 수 있으 므로, 학령 전 시기에 문법형태소의 정확한 사용과 이해 에 대한 중요성을 본 연구를 통해 확인할 수 있었다. 한편, 고기능 자폐성장애 아동의 경우 본 연구의 결과는 이들이 통사적 중의성 문장을 이해하기 위해 운율을 이용할 수 있는지 여부를 조사한 Diehl et al. (2008)의 연구 결과와 유 사하다. 이 연구에 따르면 고기능 자폐성 집단은 구문을 명확하게 이해하기 위해 운율을 이용할 가능성이 상당히 낮았지만, 구문만을 단독으로 제시한 경우 또는 운율과 구 문 모두를 응답의 정확도로 나타낸 경우에는 대조집단과 비교하여 수행이 비슷하였다. 이러한 연구 결과는 일반 아 동과 고기능 자폐성장애 아동 모두 운율 정보만으로 단서 가 주어질 때에는 문장을 이해하는 것이 더 어려우며, 고 기능 자폐성 아동은 운율 정보를 이용하여 문장의 의미를 명확하게 하는데 더 큰 어려움을 가지고 있음을 의미한다. 즉, 고기능 자폐성장애 아동의 경우 제공되는 조건에 따 라 통사적 중의성 문장 이해력에 유의한 차이가 발생된다 고 생각할 수 있다. 이러한 결과는 고기능 자폐성장애 아 동이 생활연령일치 아동에 비해 운율 지각 능력이 부족하 다는 선행 연구들에서 이미 밝혀진 바 있다(Lim and Sim, 2009; Peppé et al., 2011). 또한 두 집단의 과제 간 유의미한 차이는 고기능 자폐성장애 아동이 문법형태소와 의미적 단서들을 통합하지 못하고 사실적 단어에만 주의를 기울 여, 문장이 의미하는 전체 내용을 이해하는 데 어려움이 있다는 연구 결과를 반영한다(Ha, 2006). 특히 Myles et al. (2003)은 고기능 자폐성장애 아동은 생활연령일치 아동에 비해 표현하는 문장의 길이가 짧고, 덜 복잡한 양상을 보 인다고 하였다. 이는 형태소의 사용 능력이 생활연령일치 아동에 비해 부족함을 의미하므로, 형태소 단독 단서의 수 행력에도 어느 정도 영향을 미칠 것으로 추측할 수 있다. 그러나 본 연구의 두 집단 모두에서 발견된 흥미로운 점 은 이전 연구(Choi, 2009)와 달리 형태소 단독 정보가 제 시된 경우가 운율 형태소 복합 정보가 제시된 경우보다 상대적으로 수행력이 높았으며, 고기능 자폐성장애 아동 들은 생활연령 일치 아동에 비해 모든 단서 조건에서 문 장 이해 능력이 부족하였으나 운율+형태소 복합 단서 상 황에서 가장 큰 차이를 보인 점이다. 이는 형태소 정보가 운율 정보를 넘어 문장 의미 처리에 더 큰 기여를 하고 있으며, 실행 과제에서 요구되는 인지적 부하를 줄이면 운 율 정보가 문장 구조 결정에 관여하는 조건들에서도 아동 들의 수행력이 향상되는 양상(Snedeker and Yuan, 2008)을 보인다는 선행 연구 결과와도 일치한다. 즉, 문법형태소와 
운율 단서의 통합에도 문제가 있는 것으로 추측할 수 있 지만, 그 정확한 기전을 본 연구를 통해 결정내리기는 한 계가 있어 보인다.

본 연구의 정서적 중의성 문장 이해 과제에서 운율에 따른 정서 이해 수행력을 비교한 결과, 고기능 자폐성장 애 아동은 유의미하게 낮은 수행 수준을 보여주었다. 이 는 고기능 자폐성장애 아동이 정서적 운율 지각 능력에 제한되어 있으며, 생활연령일치 아동에 비해 운율을 활용 하여 정서적 중의성 문장을 이해할 가능성이 유의하게 낮 음을 의미한다. 기존 연구들에서도 고기능 자폐성장애 아 동의 운율 능력은 개인마다 상당히 차이를 보였으나 일반 아동에 비해서 현저히 낮았으며(Peppé et al., 2007), 특히 최소 언어적 기능을 반영하는 정서 과제(affect task)에서 가장 차이를 보여 일반 아동에 비해 부족한 정서 운율 지 각 능력을 보유하고 있음이 밝혀졌다(Diehl and Paul, 2012; Kim et al., 2013), 따라서 고기능 자폐성장애 아동은 구어 적 및 비구어적 정보 처리에 어려움을 보이는 특징을 가 지고 있으므로 상대방의 감정 이해와 사회적 의사소통에 있어서 부정적인 영향을 받게 될 가능성이 높다. 특히, 이러한 운율 지각의 결함에 대해 연구자들은 마음이론 (Baron-Cohen, 1997)이나 정서적 처리 능력의 결함(Hobson, 2005)과 관련이 있음을 제안하고 있다. 한편, 자폐성장애 인의 경우 매우 까다로운 2 차 과제로 주의를 환기시켜 인 지 기능의 부하를 증가시킨 조건에서는 문장 수준에서 정 서적 운율 처리 장애(예, 정서적 운율 처리 속도 저하)를 나타내므로(Chevallier et al., 2011), 이러한 결과는 정신 상 태의 속성 또는 마음 이론의 좀 더 일반적인 결함을 반영 할 수도 있다는 가능성이 제기되고 있기도 하다. 따라서, 일반 자폐성장애 아동과 달리 고기능 자폐성장애 아동들 이 인지 능력이나 세상 지식, 또는 학습의 영향에 의해 일 부 사회 인지(social cognition)를 습득한 상황에서 나타내 는 마음이론과 운율 정보의 활용을 문장 이해와 관련 지 어 연구해 볼 필요가 있을 것이다.

본 연구에서, 주요변수 간 상관관계를 살펴보면 고기능 자폐성장애 아동은 일반적인 문장의 이해에서 형태소 단 독 단서와 상관을 보인 반면, 생활연령일치 아동의 경우 운율 단독 단서와 정서적 운율 이해 간 상관을 보였다. 이 는 고기능 자폐성장애 아동은 문장 내에서 운율의 정서 정보보다는 문장의 문법형태소를 활용하여 정서를 인식한 다고 볼 수 있다. 일반적으로 문장을 이해할 때 우리는 운 율 정보를 이용해 얼굴 표정이나 행동에서 표현되는 마음 상태를 읽을 수 있다. 운율 지각 능력이 떨어지면, 문장의
내용을 정확하게 이해할 수 없고, 이는 문장의 전체적인 의미를 잘못 받아들이는 결과를 초래한다. 발달 초기의 아 기들 역시 운율 정보를 이용해 여러 의미 정보를 함께 처 리하며 이는 운율자동처리도 알려져 있다. 하지만, 고기능 자폐성장애 아동은 정상 발달 아동보다 통사적 중의성 문 장과 정서적 중의성 문장의 이해를 위해 운율을 활용할 수 있는 기술이 상대적으로 낮다는 사실을 본 연구를 통 해 확인할 수 있었다. 이러한 결과는 고기능 자폐성장애 아동이 일반 아동보다 운율의존도가 낮게 나타났다는 연 구(Kim et al., 2013; Kang et al., 2014)와 일치한다. 의사소통 의 언어적, 비언어적 측면과 정서적 측면에 대한 운율의 관련성을 고려할 때 운율 지각 능력을 증가시키면 의사 소통 능력도 향상될 뿐 아니라 사회적 기술도 좋아질 것 으로 생각되기 때문에 본 연구로 밝혀진 단서에 따른 수 행력을 참고하여 고기능 자폐성장애 아동의 언어적 중재 시, 자칫 지나치기 쉬운 운율 영역에 대한 중재도 고려해 야 할 것으로 생각된다.

본 연구의 제한점으로는 우선, 본 연구의 대상자 수가 비교적 제한적이기 때문에 일반화에 한계가 있다는 점을 들 수 있다. 또한, 통사적 능력(특히 형태소 단독 또는 형 태소 포함)이 요구되는 과제들에서는 두 집단 간의 차이 가 없고, 운율적 정보 해석 능력이 요구되는 과제에서만 두 집단 간의 차이가 날 때 고기능 자폐 아동들의 다른 언어 능력 대비 운율 정보 처리 능력의 특별한 제한을 논 의할 수 있지만 두 집단 모두 통사적 중의성 문장 이해의 세부 과제에서 비슷한 수행력 결과가 나타나 후속 연구는 언어연령을 일치시킨 아동을 대상으로 수행력을 비교해 보아야 할 것으로 생각된다. 특히 생활연령일치 아동만으 로 한정하여 수행력을 비교하였으므로 언어 발달 단계에 따른 운율 지각 능력을 확인할 수 없었던 점은 본 연구의 제한점으로 남는다. 무엇보다, 통사적 중의성 문장 이해 과제의 경우 이지선다형으로 구성되어 있고, 정서적 중의 성 문장 이해 과제의 경우 삼지선다형으로 구성되어 있어 우연적 정답 반응이 가능하였던 것으로 판단된다. 따라서 정답률의 신뢰도를 향상시키기 위해 각 문항 내 여러 개 의 선택 항목을 제공할 필요가 있을 것으로 생각된다. 이 와 같은 제한점을 보완하는 고기능 자폐성장애 아동의 운 율에 관한 후속 연구가 필요할 것이다.

\section{ACKNOWLEDGEMENTS}

This article was based on the first author's master's thesis from Catholic University of Pusan (2015). 


\section{CONFLICT OF INTEREST}

The authors have no conflicts of interest to disclose.

\section{REFERENCES}

American Psychiatric Association (APA). Task Force on DSM-IV. Diagnostic and statistical manual of mental disorders: DSMIV-TR (4th ed). 2000.

Baron-Cohen S. Mindblindness: An Essay on Autism and Theory of Mind. MIT Press. 1997.

Beach CM, Katz WF, Skowronski A. Children's processing of prosodic cues for phrasal interpretation. Journal of the Acoustical Society of America. 1996. 99: 1148-1160.

Bonneh YS, Levanon Y, Dean-Pardo O, Lossos L, Adini Y. Abnormal speech spectrum and increased pitch variability in young autistic children. Frontiers in Human Neuroscience. 2011. 4: 237.

Chang KH, Kim TK. The Pragmatic elements concerned with the sounds of utterance. Korean Semantics. 2005. 18: 175-196.

Chevallier C, Noveck I, Happé F, Wilson D. What's in a voice? Prosody as a test case for the theory of mind account of autism. Neuropsychologia. 2011. 49: 507-517.

Choi Y. Preschool-aged Children's Use of prosody in sentence processing. Korean Journal of Communication Disorders. 2009. 14: 442-455.

Choi Y, Mazuka R. Young children's use of prosody in sentence parsing. Journal of Psycholinguistic Research. 2003. 32: 197 $-217$.

Choi Y, Mazuka R. The Handbook of East Asian Psycholinguistics, Acquisition of prosody in Korean. Cambridge University Press. 2009.

Christophe A, Mehler J, Sebastián-Gallés N. Perception of prosodic boundary correlates by newborn infants. Infancy. 2001. 2: 385 $-394$.

Cleland J, Gibbon FE, Peppé S, O'Hare A, Rutherford M. Phonetic and phonological errors in children with high-functioning autism and Asperger syndrome. International Journal of Speech -Language Pathology. 2010. 12: 69-76.

DeMyer MK, Hingtgen JN, Jackson RK. Infantile autism reviewed: a decade of research. Schizophrenia Bulletin. 1981. 7: 388 $-451$.

DePape AMR, Chen A, Hall GBC, Trainor LJ. Use of prosody and information structure in high functioning adults with autism in relation to language ability. Frontiers in Psychology.
2012. 3: 72 .

Diehl JJ, Bennetto L, Watson D, Gunlogson C, McDonough J. Resolving ambiguity: A psycholinguistic approach to understanding prosody processing in high-functioning autism. Brain and Language. 2008. 106: 144-152.

Diehl JJ, Paul R. Acoustic differences in the imitation of prosodic patterns in children with autism spectrum disorders. Research in Autism Spectrum Disorders. 2012. 6: 123-134.

Golan O, Baron-Cohen S, Hill JJ, Rutherford M. The 'Reading the Mind in the Voice' test-revised: a study of complex emotion recognition in adults with and without autism spectrum conditions. Journal of Autism and Developmental Disorders. 2007. 37: 1096-1106.

Ha YR. A case study on a high functioning autism child's communicative deficits: focused on the deficits of understanding and expression. Journal of Special Education \& Rehabilitation Science. 2006. 45: 147-177.

Hobson RP. Handbook of Autism and Pervasive Developmental Disorders, Volume 1: Diagnosis, Development, Neurobiology, and Behavior: Autism and Emotion. Wiley and Sons. 2005.

Järvinen-Pasley A, Peppé S, King-Smith G, Heaton P. The relationship between form and function level receptive prosodic abilities in autism. Journal of Autism and Developmental Disorders. 2008. 38: 1328-1340.

Johnson EK, Jusczyk PW. Word segmentation by 8-month-olds: When speech cues count more than statistics. Journal of Memory and Language. 2001. 44: 548-567.

Kang EJ, Hwang MA, Jeong MR. Emotional recognizing ability from the prosodies of children with high-functioning autism. Journal of Emotional \& Behavioral Disorders. 2014. 30: 79 $-94$

Kim CH, Kim YT, Lee SJ. Effect of context and affective prosody on emotional perception in children with high-functioning autism. Communication Sciences and Disorders. 2013. 18. 24 -34 .

Kim TK, Kim MH. A study on the prosodic development in early childhood. Korean Language Education. 2004. 115: 87-118.

Kim TR, Park RG. Childhood autism rating scale (CARS). Seoul Special Education Publishing. Seoul. 2006.

Kim YT, Hong GH, Kim KH, Jang HS, Lee JY. Receptive \& Expressive Vocabulary Test (REVT). Seoul Community Rehabilitation Center. 2009.

Kleinman J, Marciano PL, Ault RL. Advanced theory of mind in high functioning adults with autism. Journal of Autism and Developmental Disorders. 2001. 31: 29-36. 
Kuhl PK, Coffey-Corina S, Padden D, Dawson G. Links between social and linguistic processing of speech in preschool children with autism: behavioral and electrophysiological measures. Developmental Science. 2005. 8: 1-12.

Lim SE, Sim HS. Prosodic control of high functioning autism and normal children in relation to question-statement contrast. Journal of the Korean Association for Person with Autism. 2009. 9: 37-55.

McCann J, Peppé S. Prosody in autistic spectrum disorders: A critical review. International Journal of Language and Communication Disorders. 2003. 38: 325-350.

Ministry of Education, Science and Technology (MEST). Special Education Annual Report. MEST. 2012.

Moon SB, Byun CJ. Psychoeducational assessment test: KoreanKaufman assessment battery for children (K-ABC). Hakjisa. 2009.

Myles BS, Huggins A, Rome-Lake M, Hagiwara T, Barnhil, GP, Griswold DE. Written language profile of children and youth with Asperger syndrome: research to practice. Education and Training in Developmental Disabilities. 2003. 38: 362-369.

Pae SY, Lim SS, Lee JH, Jang HS. Korea Sentence Comprehension Test (KOSECT). Seoul Community Rehabilitation Center. 2004.

Park CO. The development of emotion reading ability in prosody of language (Unpublished master's thesis) Chungbuk National University Graduate School. 2010

Paul R, Orlovski SM, Marcinko HC, Volkmar F. Conversational behaviors in youth with high-functioning ASD and Asperger syndrome. Journal of Autism and Developmental Disorders. 2009. 39: 115-125.

Paul R, Shriberg LD, McSweeny J, Cicchetti D, Klin A, Volkmar F. Brief report: relations between prosodic performance and communication and socialization ratings in high functioning speakers with autism spectrum disorders. Journal of Autism and Developmental Disorders. 2005. 35: 861-869.

Peppé S, Cleland J, Gibbon F, O'Hare A, Castilla PM. Expressive prosody in children with autism spectrum conditions. Journal of Neurolinguistics. 2011. 24: 41-43.

Peppé S, McCann J, Gibbon F, O'Hare A, Rutherford M. Receptive and expressive prosodic ability in children with high-functioning autism. Journal of Speech, Language and Hearing Research. 2007. 50: 1015-1028.

Rutherford M, Baron-Cohen S, Wheelwright S. Reading the mind in the voice: a study with normal adults and adults with Asperger syndrome and high functioning autism. Journal of Autism and Developmental Disorders. 2002. 32: 189-194.

Schoen E, Paul R, Chawarska K. Speech Sound Disorders in Children: In Honor of Lawrence D. Shriberg: Vocal production in toddlers with autism spectrum disorders. Plural Publishers. 2010.

Singh L, Harrow MS. Influences of semantic and prosodic cues on word repetition and categorization in autism. Journal of Speech, Language, and Hearing Research. 2014. 57: 1764 -1778 .

Snedeker J, Yuan S. Effects of prosodic and lexical constraints on parsing in young children (and adults). Journal of Memory and Language. 2008. 58: 574-608.

Tsai LY. High-functioning individuals with autism: Diagnostic issues in high-functioning autism. Springer. 1992.

https://doi.org/10.15616/BSL.2017.23.4.362

Cite this article as: $\mathrm{CH}$ Chung, HR Lee, JD Kim. Utilizing Prosodic Information on the Sentence Comprehension in Children with High Functioning Autism. Biomedical Science Letters. 2017. 23: 362-371. 